\title{
Pseudocohnilembus persalinus (Ciliophora: Scuticociitida) is an additional species causing scuticociliatosis in olive flounder Paralichthys olivaceus
}

\author{
Sung Mi Kim¹, Jae Bum Cho', Eun Hye Lee ${ }^{1}$, Se Ryun Kwon ${ }^{1}$, Sung Koo Kim², \\ Yoon Kwon $\mathrm{Nam}^{3}$, Ki Hong Kim ${ }^{1, *}$
}

${ }^{1}$ Department of Aquatic Life Medicine, ${ }^{2}$ Faculty of Food Science and Biotechnology, and ${ }^{3}$ Department of Aquaculture, Pukyong National University, Pusan 608-737, Korea

\begin{abstract}
In the present study, Pseudocohnilembus persalinus was first reported as a species causing scuticociliatosis in olive flounder Paralichthys olivaceus. Based on the stained specimens, $P$. persalinus was clearly differentiated from Uronema marinum, which has been shown to be a cause of scuticociliatosis in farmed olive flounder in Korea from its characteristic oral infraciliature structure. The 1754 bp small subunit ribosomal RNA (SS rRNA) gene sequence of P. persalinus showed $95 \%$ homology with the partial sequence of $P$. hargisi SS rRNA. Moreover, multiplex PCR based on the species-specific amplification of the SS rRNA gene sequence enabled us to distinguish $P$. persalinus from $U$. marinum in a simple and rapid manner. P. persalinus was clearly differentiated from $U$. marinum even when the host was infected simultaneously with both species. These data suggest that the multiplex PCR procedure would make it possible to avoid the cumbersome and time-consuming procedures of morphological analysis for the definitive identification of ciliates.
\end{abstract}

KEY WORDS: Pseudocohnilembus persalinus - Scuticociliatosis • Olive flounder · Morphology · SS rRNA gene $\cdot$ Multiplex PCR

\section{INTRODUCTION}

Scuticociliatosis caused by histophagous opportunistic scuticociliates is recognized as one of the most important worldwide parasitological problems affecting cultured marine fish. The ciliates are characterized by their high potential for systemically invading and destroying tissues, leading to high mortalities of the host. Several scuticociliate species have been reported as causative agents of scuticociliatosis in farmed marine fish including Philasterides dicentrarchi in sea bass (Dragesco et al. 1995) and turbot (Iglesias et al. 2001), Uronema nigricans in bluefin tuna (Munday et al. 1997), Uronema marinum in olive flounder (Jee et al. 2001), and other unidenti- fied species which affect olive flounder (Yoshinaga \& Nakazoe 1993).

The present paper reports the finding of another scuticociliatosis causing species, Pseudocohnilembus persalinus, from cultured olive flounder in Korea. From the comparison of morphological characteristics of stained specimens and the small subunit ribosomal RNA (SS rRNA) gene sequences, $P$. persalinus was clearly distinguished from Uronema marinum, which has been shown to be a culprit of scuticociliatosis in farmed olive flounder in Korea (Jee et al. 2001). The definitive identification of ciliate species by morphological characteristics relies on time-consuming and laborious staining techniques. Therefore, in this study, we discriminated between these 2 species by 
multiplex PCR based on the specific primers of SS rRNA genes.

\section{MATERIALS AND METHODS}

Ciliates. Ciliates were isolated from brain, gill or ulcerated skin of olive flounder Paralichthys olivaceus collected from several local fish farms in Korea, and were cultured in minimum essential medium (MEM, Sigma) supplemented with $10 \%$ fetal calf serum or in filtered seawater supplemented with autoclaved yeast extracts at $20^{\circ} \mathrm{C}$.

Staining and microscopic characteristics. Cultured ciliates were wet-mounted and observed under a differential-interference-contrast (DIC) microscope. For the study of the somatic and oral infraciliature, the ciliates were concentrated by centrifugation at $900 \times g$ for $5 \mathrm{~min}$, and then stained by the wet Chatton-Lwoff silver nitrate method described by Foissner (1991) or by the silver carbonate impregnation method described by Ma et al. (2003). To observe nuclei, ciliates were stained with Giemsa solution. The stained ciliates $(\mathrm{n}=$ 50) were measured using an ocular micrometer and image analysis software (UTHSCSA Image Tool ver. 3.0). Drawings of impregnated specimens were made with the aid of a camera lucida.

Nuclear DNA extraction, PCR amplification of SS rRNA and sequence analysis. Approximately $1 \times$ $10^{7}$ cells of cultured ciliates were pelleted by centrifugation at $900 \times g$ for $5 \mathrm{~min}$ at $4^{\circ} \mathrm{C}$ and washed 3 times with Hank's balanced salt solution (HBSS, pH 7.4, Sigma). Genomic DNA was extracted using the Accuprep ${ }^{\circledR}$ Genomic DNA Extraction Kit (Bioneer). Fifty ng of genomic DNA was used in $20 \mu \mathrm{l}$ of PCR reaction mixture containing 10 pmol of each primer and $0.5 \mathrm{U}$ of Taq DNA polymerase (Takara). The reaction was carried out for 30 cycles using an automated thermal cycler (iCycler, BioRad) at $95^{\circ} \mathrm{C}$ for $30 \mathrm{~s}, 55^{\circ} \mathrm{C}$ for $30 \mathrm{~s}$ and $72^{\circ} \mathrm{C}$ for $2 \mathrm{~min}$, with an initial denaturation at $95^{\circ} \mathrm{C}$ for $2 \mathrm{~min}$. Two oligonucleotide universal SS rRNA primers, U 1F (5'-AACCTGGTTGATCCGCCA-G-3') and U 1R (5'-TGATCCATCTGCAGGTTCAC-3'), were used to amplify the SS rRNA gene. The amplified PCR product was cloned into a PCR 2.1-TOPO plasmid using the TOPO TA Cloning ${ }^{\circledR}$ Kit (Invitrogen), and the recombinant plasmid was purified using an Accuprep ${ }^{\circledR}$ Plasmid Extraction Kit (Bioneer) for the sequencing experiment. The sequencing reaction was carried out using BigDye terminator (Applied Biosystems) according to the manufacturer's recommendations, and the sequences were analyzed with an Automated DNA Sequencer (ABI Prism 377, Applied Biosystems).
Multiplex PCR. The SS rRNA gene sequences of Pseudocohnilembus persalinus and Uronema marinum obtained from the present study were aligned with the previously known SS rRNA genes of $U$. marinum (GenBank accession no. Z22881 partial sequence) and P. hargisi (GenBank accession no. AY212806). Based on sequence comparison, 3 hyper-variable regions were selected to construct PCR primers for the speciesspecific amplification of SS rRNA gene segments using multiplex PCR. The sequence and location of each forward and reverse primer used are shown in Fig. 3. To perform the multiplex PCR, equal amounts of 4 oligonucleotides (10 pmol each) were included in a PCR reaction. The reaction mixture $(20 \mu \mathrm{l})$ was carried out for 30 cycles at $95^{\circ} \mathrm{C}$ for $30 \mathrm{~s}, 50^{\circ} \mathrm{C}$ for $30 \mathrm{~s}$ and $72^{\circ} \mathrm{C}$ for $30 \mathrm{~s}$. Five $\mu \mathrm{l}$ of amplified PCR product was separated using a $1 \%$ agarose gel and visualized using ethidium bromide staining. The expected sizes of the PCR products are 421 and $722 \mathrm{bp}$ for $P$. persalinus and $U$. marinum, respectively.

\section{RESULTS}

\section{Morphological characteristics of Pseucohnilembus persalinus}

The ciliates were elongated, spindle-shaped (Fig. 1A) and measured 29 to $42 \mu \mathrm{m}$ in length and 15 to $19 \mu \mathrm{m}$ in width. A large globular macronucleus and a small micronucleus were located at the level of the buccal entrance (Fig. 2G). The posterior cytoplasm was filled with numerous food vacuoles (Fig. 2H). The somatic ciliatures were sparsely arranged, consisting of 8 to 11 bi-polar kineties made up of 15 to 18 kinetids.

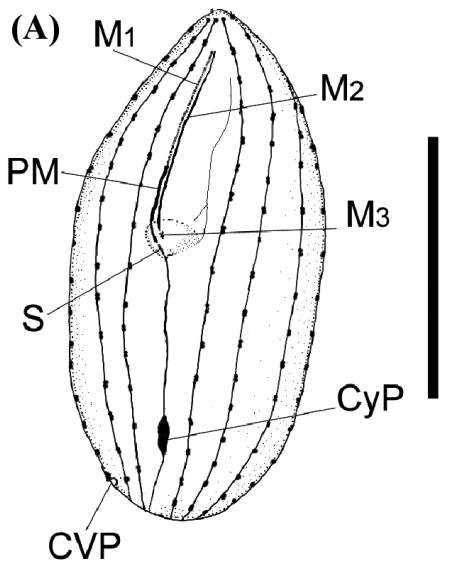

(B)

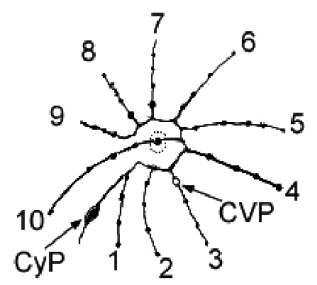

Fig. 1. Pseudocohnilembus persalinus. (A) Ventral view of silver impregnated specimen. CyP: cytopyge; CVP: pore of contractile vacuole; $\mathrm{M}_{1}-\mathrm{M}_{3}$ : membranelles $1-3$; PM: paroral membrane; S: scutico-vestige. Scale bar $=15 \mu \mathrm{m}$. (B) Caudal view of silver impregnated specimen 

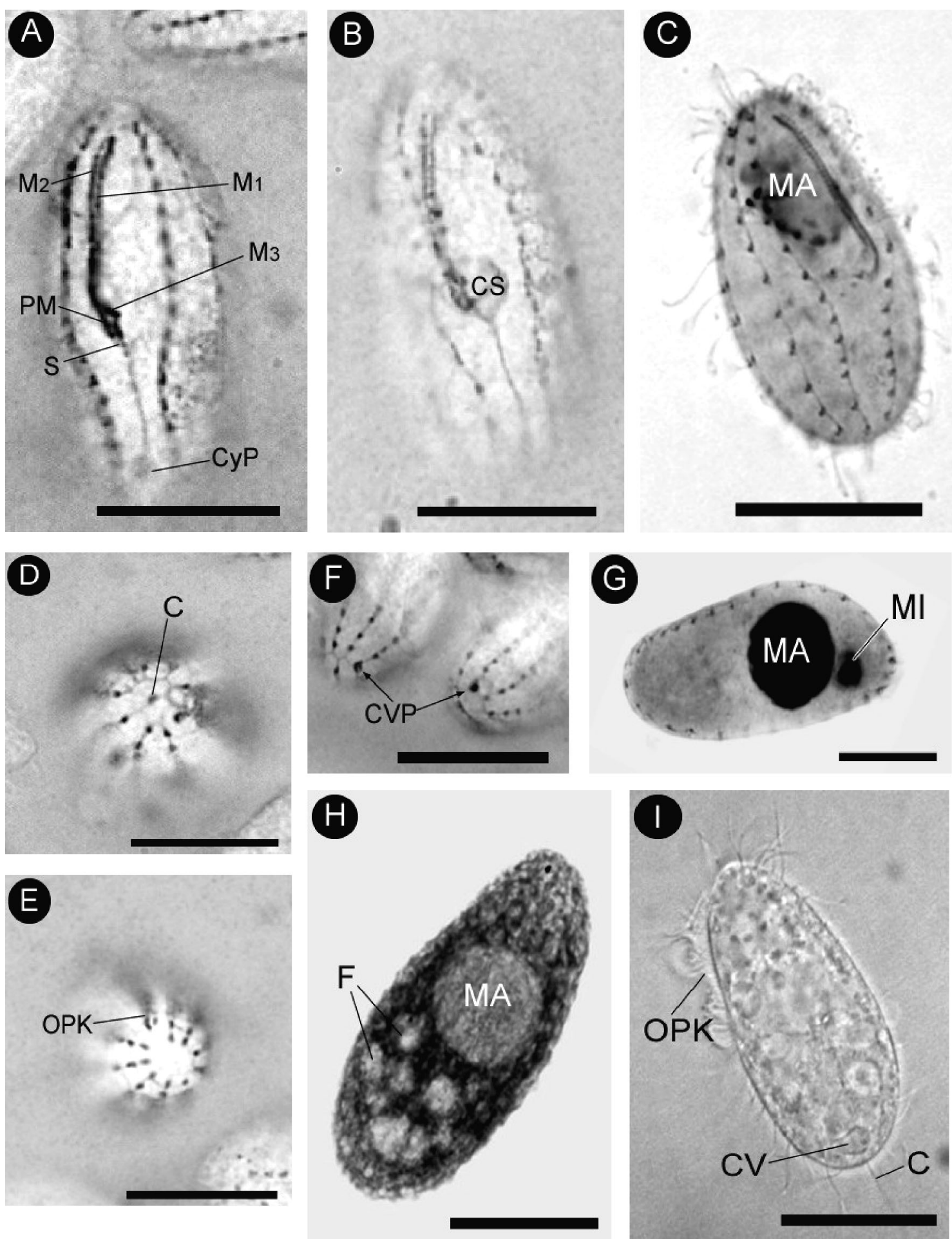

Fig. 2. Pseudocohnilembus persalinus. Silver impregnated ciliates. (A,B) Wet silver impregnated; (C) silver carbonate impregnated. Buccal apparatus composed of paroral membrane (PM), 3 oral membranelles $\left(\mathrm{M}_{1}-\mathrm{M}_{3}\right)$, cytostome (CS), scutico-vestige (S), cytopyge (CyP), macronucleus (MA). (D). Posterior end of wet silver impregnated ciliate. C: caudal cilium. (E) Apical pole of wet silver impregnated ciliate. OPK: oral polykinetids. (F) Wet silver impregnated ciliate contractile vacuole pore (CVP) at posterior pole. (G) Silver carbonate impregnated ciliate with macro- (MA) and micronucleus (MI). (H) Giemsa-stained ciliate showing a macronucleus (MA) and numerous food vacuoles (F). (I) Live ciliate observed under the differential interference contrast microscope. $\mathrm{CV}$ : contractile vacuole. Scale bars $=10 \mu \mathrm{m}$ 


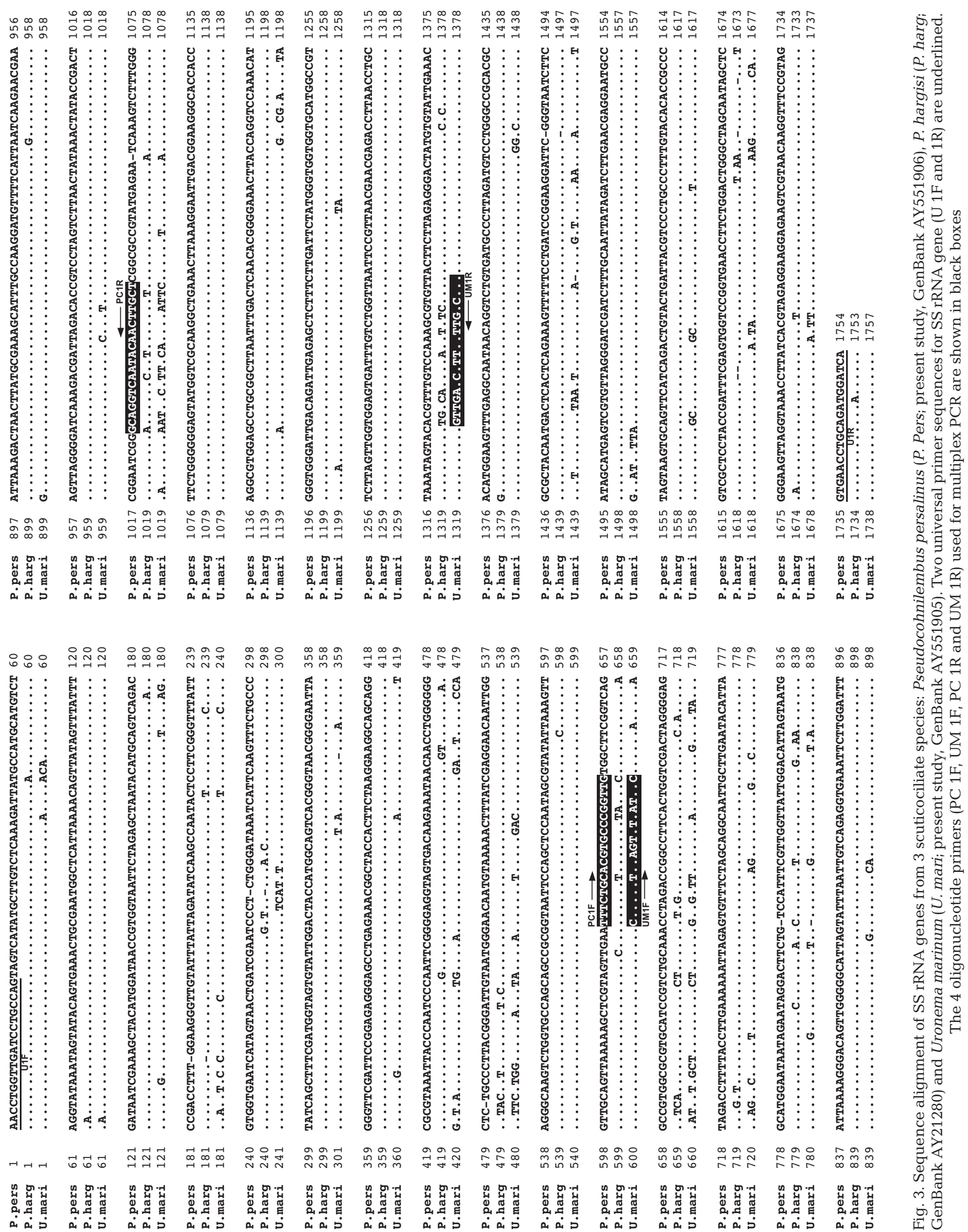


A non-ciliated director-meridian began just posterior to the scutica and merged with the first kinety at the posterior pole (Figs. 1B \& 2D). The cytopyge, a thick argentophilic patch, was located subcaudally (Figs. 1 \& 2A). A contractile vacuole pore (CVP) opened at the posterior end of the third somatic kinety (Figs. 1 \& 2F,I).

The buccal field was 15 to $18 \mu \mathrm{m}$ in length and occupied the anterior half of the body (Figs. 1A \& 2A-C). The buccal apparatus consisted of 3 membranelles: $M_{1}$ was a single row and located just anterior to the paroral membrane (PM); $\mathrm{M}_{2}$ was also a single row and was parallel to $\mathrm{M} 1$ and $\mathrm{PM} ; \mathrm{M}_{3}$ was very small and located at the end of the PM (Figs. 1A \& 2A-C,E,I). The paroral membrane was gently curved and positioned at the right side of the buccal cavity (Figs. 1A \& 2A-C).

\section{SS rRNA gene sequence and multiplex PCR}

The SS rRNA sequences of Uronema marinum and Pseudocohnilembus persalinus determined from this study were 1757 and $1754 \mathrm{bp}$, respectively. These sequences were deposited in GenBank under the accession numbers AY551905 for $U$. marium and AY551906 for $P$. persalinus. The present $U$. marinum SS rRNA sequence exactly matched when aligned with the previously known 1680 bp of the partial U. marinum sequence (GenBank Z22881) except for 6 nucleotide bases, possibly indicating that there might be some sequence differences in SS rRNA genes among $U$. marinum strains. The $1754 \mathrm{bp}$ of the SS rRNA gene sequence from $P$. persalinus shared high homology with those from other scuticociliate species, and showed $95 \%$ identity with the $P$. hargisi SS rRNA gene partial sequence (GenBank AY212806) (Fig. 3).

Using the 4 oligonucleotide primers which were designed based on the variable regions on the SS rRNA sequences, Pseudocohnilembus persalinus and Uronema marinum were clearly distinguished from each other by multiplex PCR. Most of the PCR reactions generated a PCR product which clearly matched the size of the SS rRNA gene segment amplified either from $P$. persalinus (421 bp) or U. marinum (722 bp). Multiplex PCR amplification of DNA of scuticociliate species isolated from fish sampled at several olive flounder farms located in Hansando, Pohang-A or Haeundae revealed a single band of $412 \mathrm{bp}$, indicating the fish should be infected only with $P$. persalinus (Fig. 4). On the other hand, only a $722 \mathrm{bp}$ amplification product was obtained from olive flounder sampled from Jeju, suggesting that $U$. marinum was responsible for scuticociliatosis from this site. Interestingly, the multiplex PCR products with DNA of scuticociliates isolated from the fish sampled from Pohang-B displayed both sizes of PCR bands (421 and 722 bp), indi-

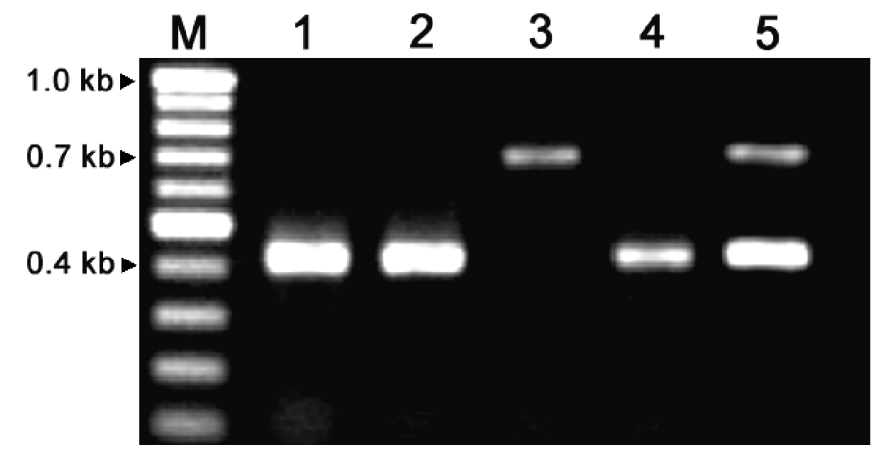

Fig. 4. Ethidium bromide-stained $1.0 \%$ agarose gel showing the multiplex PCR products amplified with DNA of scuticociliates isolated from diseased olive flounder collected at Hansando (Lane 1), Pohang-A (Lane 2), Jejudo (Lane 3), Haeundae (Lane 4) and Pohang-B (Lane 5). Lane $\mathrm{M}$ is a $1 \mathrm{~kb}$ molecular weight ladder (Bioneer)

cating the fish were infected with both $P$. persalinus and $U$. marinum.

\section{DISCUSSION}

In the present study, Pseudocohnilembus persalinus was first reported as a species causing scuticociliatosis in olive flounder Paralichthys olivaceus. P. persalinus was originally described by Evans \& Thompson (1964) based on silver nitrate impregnated specimens and was recently described again by Song (2000). Although there are different opinions on the taxonomic identity of this species (Thompson 1965, 1966, Foissner \& Wilbert 1981, Song 2000), morphological characteristics of the present specimens coincided well with the characteristics of P. persalinus (Table 1).

Table 1. Pseudocohnilembus persalinus. Morphometric comparisons between the present specimens and those of Song (2000). CVP: contractile vacuole pore

\begin{tabular}{|lcc|}
\hline Characteristics & $\begin{array}{c}\text { Present } \\
\text { specimens }\end{array}$ & Song (2000) \\
\hline Body length $(\mu \mathrm{m})$ & $29-42$ & $25-43$ \\
$\begin{array}{l}\text { Body width }(\mu \mathrm{m}) \\
\text { Length of buccal field }(\mu \mathrm{m})\end{array}$ & $15-19$ & $15-23$ \\
$\begin{array}{l}\text { Length of buccal field: } \\
\text { body length ratio }\end{array}$ & $0.41-0.60$ & $0.46-0.59$ \\
$\begin{array}{l}\text { Number of somatic } \\
\text { kineties (SK) }\end{array}$ & $8-11$ & $9-11$ \\
$\begin{array}{l}\text { Number of basal } \\
\text { bodies in SK1 }\end{array}$ & $15-18$ & $17-21$ \\
$\begin{array}{l}\text { Position of CVP, located at } \\
\text { the end of SK }\end{array}$ & SK3 & SK3 \\
$\begin{array}{l}\text { Habitats } \\
\text { Geographical distribution }\end{array}$ & $\begin{array}{c}\text { Marine } \\
\text { South Korea }\end{array}$ & $\begin{array}{c}\text { Marine } \\
\text { China }\end{array}$ \\
\hline
\end{tabular}


Based on the stained specimens, Pseudocohnilembus persalinus was clearly differentiated from Uronema marinum by its characteristic oral infraciliature structure. Moreover, the multiplex PCR based on the species-specific amplification of SS rRNA gene sequence enabled us to distinguish $P$. persalinus from $U$. marinum in a simple and rapid manner. $P$. persalinus was clearly differentiated from $U$. marinum even in the host infected with both species. These data suggest that the multiplex PCR procedure would make it possible to avoid the cumbersome and time-consuming procedures of morphological analysis for the definitive identification of ciliates.

Although several attempts have been made to treat scuticociliatosis by various chemotherapeutics (Iglesias et al. 2002, Quintela et al. 2003), there is at present no effective in vivo chemotherapeutic treatment, especially for internal infections. Therefore, development of an effective vaccine may be the best way to control scuticociliatosis. Recently, Iglesias et al. (2003) reported that Philasterides dicentrarchi expressed immobilization antigens (i-antigens) on its surface which were recognized by the turbot immune system and which might be useful for vaccination. However, they pointed out the existence of different serotypes of the ciliate and that there were outbreaks of the disease in turbot by another scuticociliate, U. marinum, which probably expresses i-antigens of its own. Thus, identification and differentiation of ciliate species responsible for scuticociliatosis in a host species should be the first step for development of effective vaccines.

Although in the present study Pseudocohnilembus persalinus was reported as another species causing scuticociliatosis, it cannot be ruled out that other scuticociliate species may be involved in scuticociliatosis in olive flounder and more extensive studies are needed.

Acknowledgements. This study was supported by a grant from the Ministry of Maritime Affairs and Fisheries, Republic of Korea.

\section{LITERATURE CITED}

Dragesco A, Dragesco J, Coste F, Gasc C, Romestand B, Raymond J, Bouix G (1995) Philasterides dicentrarchi, n. sp. (Ciliophora, Scuticociliatida), a histophagous opportunistic parasite of Dicentrachus labrax (Linnaeus. 1758), a

Editorial responsibility: Wolfgang Körting,

Hannover, Germany reared marine fish. Eur J Protistol 31:327-340

Evans FR, Thompson JC (1964) Pseudocohnilembidae n. fam., a hymenostome ciliate family containing one genus, Pseudocohnilembus n. g., with three new species. J Protozool 11:344-352

Foissner W (1991) Basic light and scanning electron microscopic methods for taxonomic studies of ciliated protozoa. Eur J Protistol 27:313-330

Foissner W, Wilbert N (1981) A comparative study of the infraciliature and silverline system of the fresh-water scuticociliates Pseudocohnilembus putrinus (Kahl, 1928) nov. comb., P. pusillus (Quennerstedt, 1869) nov. comb., and the marine forms P. marinus Thompson, 1966. J Protozool 28:291-297

Iglesias R, Paramá A, Álvarez MF , Leiro J, Fernández J, Sanmartín ML (2001) Philasterides dicentrarchi (Ciliophora, Scuticociliatida) as the causative agent of scuticociliatosis in farmed turbot Scophthalmus maximus in Galicia (NW Spain). Dis Aquat Org 46:47-55

Iglesias R, Paramá A, Álvarez MF, Leiro J, Sanmartín ML (2002) Antiprotozoals effective in vitro against the scuticociliate fish pathogen Philasterides dicentrarchi. Dis Aquat Org 49:191-197

Iglesias R, Paramá A, Álvarez MF, Leiro J, Ubeira FM, Sanmartín ML (2003) Philasterides dicentrarchi (Ciliophora: Scuticociliatida) expresses surface immobilization antigens that probably induce protective immune responses in turbot. Parasitology 126:125-134

Jee BY, Kim YC, Park MS (2001) Morphology and biology of parasite responsible for scuticociliatosis of cultured olive flounder Paralichthys olivaceus. Dis Aquat Org 47:49-55

Ma H, Choi JK, Song W (2003) An improved silver carbonate impregnation for marine ciliated protozoa. Acta Protozool 42:161-164

Munday BL, O'Donoghue PJ, Watts M, Rough K, Hawkesford $T$ (1997) Fatal encephalitis due to the scuticociliate Uronema nigricans in sea-caged, southern bluefin tuna Thunnus maccoyii. Dis Aquat Org 30:17-25

Quintela JM, Peinador C, González L, Iglesias R, Paramá A, Álvarez F, Sanmartín ML, Riguera R (2003) Piperazine Nsubstituted naphthyridines, pyridothienopyrimidines and pyridothienotriazines: new antiprotozoals active against Philasterides dicentrarchi. Eur J Med Chem 38:265-275

Song W (2000) Morphological and taxonomical studies on some marine scuticociliates from China Sea, with description of two new species, Philasterides armatalis sp. n. and Cyclidium varibonneti sp. n. (Protozoa: Ciliophora: Scuticociliatida). Acta Protozool 39:295-322

Thompson JC (1965) Pseudocohnilembus longisetus, a hymenostome ciliate from Antarctica. VA J Sci 16:165-169

Thompson JC (1966) Pseudocohnilembus marinus n. sp., a hymenostome ciliate from the Virginia coast. J Protozool 13:463-465

Yoshinaga T, Nakazoe J (1993) Isolation and in vitro cultivation of an unidentified ciliate causing scuticociliatosis in Japanese flounder (Paralichthys olivaceus). Gyobyo Kenkyu 28:131-134

Submitted: February 23, 2004; Accepted: July 16, 2004

Proofs received from author(s): November 3, 2004 